\title{
SAMPAH PLASTIK PENGHASIL UANG MENGHADAPI PANDEMI COVID-19
}

\section{Money-Generating Plastic Waste Facing The Covid-19 Pandemic}

\author{
Aan Kunaedi ${ }^{1}$, Tri Budi Prasetyo ${ }^{2}$, Fanny reza rahadyan², Fatimah $^{2}$, Muhammad \\ fajri $^{2}$ \\ ${ }^{1}$ Sekolah Tinggi Farmasi Muhammadiyah Cirebon; \\ ${ }^{2}$ Universitas Muhammadiyah Cirebon \\ ankunaedi@gmail.com
}

\begin{abstract}
ABSTRAK
Dampak Corona virus disease 2019 (Covid-19) terhadap seluruh aspek kehidupan, dimulai kalangan kecil hingga skala negara sedunia. Tak terkecuali aspek ekonomi yang berdampak pada seluruh dunia. (Anjaeni, 2020) melaporkan bahwa lembaga keuangan dunia yang dikenal dengan International Monetary Fund (IMF) memprediksikan perekonomian global akan menurun hingga minus $-3 \%$. Kementerian Keuangan Indonesia memaparkan delapan dampak covid-19 bagi perekonomian Indonesia, diawali dari tenaga kerja hingga produktifitas industri di indonesia (Febrianto, 2020), merupakan dampak masif yang mempengaruhi pada seluruh hingga aspek sosial dan perekonomian Indonesia. Penurunan ekonomi sangat dirasa oleh masyarakat menengah ke bawah, PHK besar-besaran, serta pedagang kaki lima yang harus tutup karena peraturan pemerintah dalam penanganan antisipasi penyebaran Covid-19. Untuk stimulan menguatkan ekonomi masyarakat menengah ke bawah dan menciptakan ekonomi kreatif maka berinisiatif membuat kegiatan memanfaatkan barang bekas menjadi barang bernilai jual. Penumpukan sampah plastik dan kertas merupakan masalah besar lingkungan hidup yang perlu mendapat perhatian khusus, salah satu cara mananggulangi sampah plastik dan kertas adalah dengan mendaurulang menjadi produk bernilai jual seperti hiasan dan tas-tas cantik. Kuliah Kerja Mahasiswa sebagai bentuk pengabdian kepada masyarakat, bekerjasama dengan aparat Desa Astana GunungJati dengan koordinasi ibu-ibu rumah tangga, berkreasi memberikan stimulus kreatifitas terhadap warga Desa Astana Kecamatan GunungJati membuat kegiatan pemanfaatan barang bekas tersebut menjadi barang nilai jual dalam program kerja "SAMPAH PLASTIK Menjadi UANG Menghadapi Pandemi Covid-19" Program atau kegiatan ini dibagi menjadi 3 (tiga) tahap, yakni (a) pemaparan materi tentang pemanfaatan barang bekas (sampah plastik dan kertas); (b) pengumpulan barang bekas rumah tangga dari lingkungan sekitar ; (c) pembuatan barang-barang hias dan tas-tas cantik dari daur ulang sampah lingkungan sekitar. Pemanfaatan sampah plastik dan kertas dapat menciptakan lingkungan bersih serta hasilnya bisa untuk menguatkan ekonomi kreatif masyarakat dengan bahan-bahan yang mudah dijangkau terutama dimasa pandemi Covid-19.
\end{abstract}

Kata kunci : Sampah plastik, ekonomi, kreativitas

\begin{abstract}
The presence of the corona virus or coronavirus disease 2019 (covid-19) has made the economic situation around the world worse. In fact, world financial institutions such as the International Monetary Fund (IMF) have projected that the
\end{abstract}


global economy will grow at minus 3\%. The government, through the Ministry of Finance, has recorded at least eight main impacts of the outbreak of Covid-19 on the Indonesian economy, from labor to industrial performance in the country. This impact has massively destroyed the social and economic foundations of Indonesia. The impact of the economic downturn was felt by the middle to lower class people, massive layoffs, and street vendors who had to close because of government regulations for handling Covid-19. To strengthen the economy of the lower middle class and create a creative economy, namely by utilizing used goods (plastic and paper waste) into goods of sale value. The accumulation of plastic and paper waste is an environmental problem that must be dealt with. One way to overcome the amount of plastic and paper waste is to use it as selling value items such as decorations and beautiful bags. This activity is in collaboration with the Astana Village government, GunungJati District and involves housewives. The activity is divided into 3 (three) stages, namely (a) explanation of general material on the use of used goods (plastic and paper waste); (b) preparation and collection; (c) manufacture of decorative items and beautiful bags from plastic and paper waste. The use of plastic and paper waste can create a clean environment and the results can strengthen the creative economy of the community with materials that are easily accessible during the Covid-19 pandemic.

Keywords : Plastic waste, economy, creativity

\section{PENDAHULUAN}

Adanya corona virus disease 2019 (covid-19) yang mempengaruhi seluruh aspek kehidupan, seluruh kalangan hingga seluruh dunia. Aspek sosial, agama, terutama perekonomian yang memburuk dirasakan seluruh masyarakat dunia. Pemberitaan (Anjaeni, 2020), memaparkan bahwa lembaga keuangan dunia yang dikenal International Monetary Fund (IMF) memperkirakan perekonomian global menurun hingga minus 3\%. Negara Berkembang seperti Indonesia tentu sangat merasakan dampak pandemi Covid-19 diseluruh aspek kehidupan.

(Febrianto, 2020) melaporkan bahwa data Kementerian Keuangan Indonesia, minimal delapan dampak adanya covid-19 terhadap perekonomian Indonesia, diawali tenaga kerja hingga produktifitas industri di Indonesia. Dampak luas dari pandemi yang berpengaruh pada seluruh aspek hingga sosial dan perekonomian Indonesia diantaranya peningkatan Pemutusan Hubungan Kerja (PHK). Hingga pandemi Covid-19 berakibat meningkatkan kesengsaraan lebih luas sektor pekerja formal maupun informal. Data Kementerian Keuangan kisaran 1,5 juta jiwa lebih merumahkan pekerja akibat terkena PHK dengan prosentase 90 persen dirumahkan dan 10 persen PHK. Terdiri dari pekerja formal sejumlah 1,24 juta dan pekerja informal sejumlah 265.000. Yang berakibat masyarakat tidak mempunyai kegiatan dirumah akibat PHK tersebut.

Kuliah Kerja Mahasiswa sebagai salah satu bentuk pengabdian kepada masyarakat juga merupakan salah satu pembelajaran bagi mahasiswa untuk peduli dan belajar langsung dimasyarakat dengan berbagai karakter dan kultur budaya. Dengan adanya kasus ekonomi akibat dampak Pandemi COVID-19 menginisiatif program kerja yang diharapkan mampu 
membantu dan memperbaiki kondisi masyarakat saat pandemi ini. Berdasarkan hasil survei dan diskusi dengan perangkat Desa Klayan untuk membantu perekonomian warga Klayan dengan mengadakan kegiatan pemanfaatan barang bekas seperti sampah plastik dan koran bekas dan sosialisasi pemanfaatan sosial media sebagai sarana bisnis penunjang perekonomian pada era Covid-19.

Sampah merupakan salah satu permasalahan yang cukup sulit ditangani di Indonesia. Hal ini terjadi karena kebiasaan masyarakatnya sebagai konsumen yang selalu menghasilkan sampah terutama plastik pada setiap pemakaian produk. Seiring dengan perkembangan teknologi kebutuhan plastik terus meningkat, plastik merupakan bahan anorganik buatan yang tersusun dari bahan-bahan kimia yang sukar diuraikan sehingga berbahaya bagi lingkungan. Sampah tersebut menjadi permasalahan lingkungan karena kuantitas maupun tingkat bahayanya mengganggu kelangsungan makhluk hidup.

Selain itu Keberadaan sampah di kehidupan sehari-hari tak lepas dari tangan manusia yang membuang sampah sembarangan, mereka menganggap barang yang telah dipakai tidak memiliki kegunaan lagi dan membuang dengan seenaknya sendiri. Kurang kesadaran akan pentingnya kebersihan menjadi faktor yang paling dominan, di samping itu kepekaan masyarakat terhadap lingkungan yang masih kecil. Masyarakat masih belum menyadari bahaya apa yang akan terjadi apabila tidak dapat menjaga lingkungan sekitar. Oleh karena itu dengan mengubah sampah plastik menjadi barang yang dapat digunakan kembali dapat membantu mengurangi pencemaran lingkungan, selain sampah anorganik yang dijadikan menjadi sebuah kerajinan yang mempunyai nilai jual, masyarakat juga bisa memanfaatkan sampah organik seperti kertas atau koran bekas untuk dijadikan sebuah kerajinan tangan.

Kreativitas pemanfaatan sampah plastik menjadi kerajinan tangan adalah solusi yang cukup baik untuk mengubah barang bekas menjadi menjadi barang yang berguna kembali, bahkan memiliki nilai jual serta dapat dikreasikan menjadi barang yang mempunyai nilai estetika. Kreativitas dalam diri seseorang dapat ditumbuhkan melalui banyak cara, salah satunya yaitu dengan membuat kerajinan tangan. Sampah plastik dan koran dapat dibuat kerajinan tangan seperti tas belanja, hiasan kamar, dompet, lampu hias, tempat pensil, keranjang, dan lain lain.

Pemanfaatan barang bekas dapat dijadikan sebagai alternatif bagi masyarakat Desa klayan untuk berlaku bijak terhadap sampah sehingga dapat memberikan manfaat baik dari segi penggunaan bahan daur ulang barang bekas maupun untuk peningkatan penghasilan keluarga dengan menjual produk daur ulang yang sudah dihasilkan, terlebih di masa Pandemi COVID-19 yang melanda Indonesia dan negara lain. Bahan yang digunakan banyak ditemui di lingkungan sekitar sehingga tidak memerlukan biaya besar hanya dengan bermodalkan keterampilan dalam memanfaatkannya. 
Prioritas sasaran kegiatan ini adalah masyarakat Desa Klayan yaitu khususnya ibu-ibu PKK. Desa Klayan merupakan salah satu desa yang terletak di Kecamatan Gunung jati Kabupaten Cirebon, merupakan desa yang terkenal dengan masyarakatnya yang kreatif. Ratarata pendidikan masyarat Desa Klayan tingkat Sekolah Menengah Atas, bahkan ada juga yang hanya Sekolah Menengah Pertama. Di desa Paowan terdapat beberapa orang yang dapat melanjutkan sekolah hingga perguruan tinggi. Hal tersebut dikarenakan faktor perekonomian masyarakat untuk melanjutkan sekolah ke jenjang yang lebih tinggi.

Rata-rata pekerjaan masyarakat di desa Klayan yakni pedagang, buruh, dan ibu rumah tangga, dengan bermodal pendidikan yang relatif rendah menjadikan kesulitan mendapatkan pekerjaan yang lebih baik dan menjadikan banyak masyarakat pengangguran. Di desa ini juga terdapat profesi sebagai guru dan sudah PNS meskipun hanya beberapa.

Warga desa Klayan masih banyak yang belum memperhatikan kebersihan lingkungan. Sehingga masih banyak masyarakat yang membuang sampah di sembarang tempat. Meski terdapat tempat pembuangan sampah, namun belum dikelola dengan baik sehingga sebagian masyarakat hanya bisa dibakar saja oleh masyarakat sendiri. Di desa Klayan sendiri banyak sekali sampah plastik dan koran yang tidak dimanfaatkan, sehingga dalam program ini dapat melakukan pelatihan yang dapat memanfaatkan barang bekas sebagai kerajian tangan dan bernilai jual yang ekonomi.

\section{BAHAN DAN METODE}

Rancangan kegiatan yang dilakukan yaitu kegiatan pelatihan mengolah dan memanfaatkan sampah plastik menjadi bantal. Kegiatan ini dilaksanakan pada hari jum'at tanggal 14 Agustus 2020 di Sanggar Banjar Patoman. Kegiatan ini berkerjasama dengan pemerintah Desa dan melibatkan ibu-ibu PKK dalam kegiatan tersebut. Alat dipersiapkan seperti gunting, lilin, korek, benang, pralon, kayu. Sedangkan bahan yang dibutuhkan yaitu sampah plastic, kemasan plastik kopi dan sejenisnya, dan koran. Adapun kegiatannya dibagi dalam 3 (tiga) tahapan yaitu: a) Survey lokasi : Tahap persiapan ini, dengan melakukan koordinasi secara intensif dengan anggota (tim) dan perangkat desa sebelum pelaksanaan kegiatan, dengan tujuan agar pelaksanaan kegiatan pengabdian kepada masyarakat dapat berjalan lancar. Persiapan pelaksanaan meliputi: menyiapkan materi penyuluhan, menyiapkan pemateri/narasumber, persiapan konsumsi, daftar hadir, spanduk, dokumentasi dan perlengkapan lain yang dibutuhkan terkait pelaksanaan kegiatan. Langkah ini dilakukan tim pengusul agar program pengabdian kepada masyarakat ini berjalan lancar dan tepat sasaran sesuai dengan tujuan dilakukannya pengabdian kepada masyarakat. b) Penjelasan materi umum tentang pemanfatan sampah dan digital marketing, metode yang digunakan yakni dengan penjelasan materi dan langsung mempraktikkan di handpone masing-masing peserta. c) 
Tahapan kreatifitas produk memanfaatkan sampah plastik. Hasil pembuatan tersebut bisa digunakan sendiri guna mempercantik rumah dan juga dijual sesuai pasar yang diinginkan.

\section{HASIL}

Hasil kegiatan ini adalah meningkatkan kreatifitas dan ketrampilan warga Desa Klayan Kecamatan Gunung Jati Kabupaten Cirebon khususnya ibu-ibu PKK, mengurangi sampah dilingkungan sekitar dengan dimanfaatkan daur ulang menjadi produk berestetika dan bernilai ekonomi, sekaligus meningkatkan kesadaran terhadap lingkungan sekitar. Sesuai harapan dari kegiatan ini dapat dihasilkan beberapa karya produk sesuai ditampilkan pada gambar 4. Melalui kegiatan ini diharapkan dapat membuka dan meningkatkan wawasan sekaligus kreatifitas ibuibu PKK wilayah setempat, dan meminimalisir peningkatan sampah dengan mendaur ulang sampah menjadi produk yang memiliki estetika dan nilai ekonomi dan meningkatnya kesadaran terhadap lingkungan sekitar.

\section{PEMBAHASAN}

Pelaksanan kegiatan disesuaikan jadwal yang telah ditetapkan dan disepakati bersama masyarakat setempat, yaitu ibu-ibu PKK. Tahapan persiapan, ditunjukkan gambar 1. dimulai observasi dan permohonan izin kepada perangkat Desa Klayan Kecamatan Gunung jati sebagai tempat pelaksanaan pengabdian. Pendataan jumlah peserta dan kegiatan peserta sebelum diadakan pelatihan kepada ibu-ibu PKK di desa Klayan Kecamatan Gunung Jati. Pelatihan dilaksanakan berupa sosialisasi dan praktik pemanfaatan barang-barang bekas (sampah) menjadi barang yang bernilai ekonomi guna peningkatan produktivitas jiwa entrepreneur ibu-ibu rumah tangga. Dengan kegiatan pelatihan ini, diharapkan dapat menciptakan kreativitas, meningkatkan keterampilan ibu-ibu dalam pemanfaatan barang-barang bekas menjadi barang yang bernilai ekonomi sehingga dapat meningkatkan pendapatan masyarakat di Desa Klayan kecamatan Gunung Jati.

Tahap pelaksanaan dimulai dengan diskusi penyiapan bahan-bahan yang dibutuhkan pelatihan, penugasan materi pembicara, persiapan peserta pelatihan, pemilihan materi pelatihan terkait pemanfaatan dan kreatifitas barang-barang bekas menjadi produk bernilai ekonomi dan estetika. Tahapan pelaksanaan kegiatan dilaksanakan sesuai dengan waktu yang telah di sepakati pada tanggal 15 Agustus 2020 bertempat di Sanggar Banjar Patoman Desa Klayan Kecamatan Gunung Jati. Tahapan pelaksanaan kegiatan dimulai dengan menjelaskan materi tentang Entrepreneur, manfaat dari berwirausaha, dan peluangpeluang usaha untuk memotivasi peserta dalam pemanfaatan barangbarang bekas yang bernilai ekonomi bagi peningkatan produktivitas jiwa entrepreneur yang ditunjukkan oleh gambar 2. 
Tahapan pelaksanan selanjutnya yaitu demonstrasi pembuatan souvenir dari barang bekas sampai souvenir siap untuk dijual. Tahapan pelatihan diberikan kepada setiap peserta berupa uraian atau langkah-langkah pembuatan produk, pembuatan produk dari botol bekas, pembuatan produk dari koran bekas, pembuatan produk dari plastik kemasan bekas. Arahan dan tanya jawab berlangsung pada saat kegiatan berlangsung yang ditunjukkan gambar 3. Instruktur menjelaskan langkah-langkah pembuatan souvenir dari barang bekas yang berbahan bekas, koran bekas, plastik kemasan makanan bekas dan langsung mendemostrasikan kepada peserta. Pelatihan berlangsung mulai pukul $08.00-13.00$ WIB.

Setelah melakukan pelatihan pembuatan pengeloaan sampah ada beberapa hasil karya yang dihasilkan seperti tas yang terbuat dari plastik, tempat tissu, tempat makanan, dan tempat penutup lampu. Kendala pelaksanaan pelatihan yakni peserta ibu-ibu PKK tidak sepenuhnya datang sesuai data tahap awal, dikarenakan mengurus keluarga dan kepentingan lain. Pelatihan pun sedikit terganggu karena sebagian ibu-ibu PKK datang bersama anaknya berusia balita, sehingga pada saat penyampaian materi ibu-ibu kurang fokus.

Melalui pelatihan pemanfaatan barang bekas ini di harapkan dapat membuka wawasan dan kreatifitas ibu-ibu PKK desa klayan dalam mengaplikasikan kreatifitas pemanfaatan barang bekas dari lingkungan sekitar. Sehingga harapan pengurangan sampah dan meningkatkan perekonomian masyarakat dapat tercapai.

\section{KESIMPULAN DAN SARAN}

Dengan mengadakan pelatihan memanfaatkan barang bekas menjadi barang yang bernilai dapat memberikan pengalaman tersendiri bagi ibu-ibu PKK untuk menambah pengetahuan dan ketrampilan memanfaatkan barang bekas menghasilkan produk layak pakai, mempunyai estetika dan layak dikomersikan, sehingga diharapkan menambah kreasi perabot rumah skaligus menambah perekonomian keluarga.

\section{UCAPAN TERIMA KASIH}

Ucapkan terima kasih kepada Allah SWT yang telah memberikan kelancaran pada setiap kegiatan yang kami laksanakan. Kepada Bapak Iman Sahudi selaku Kuwu Desa Klayan beserta jajarannya. Masyarakat Desa Klayan yang telah berpartisipasi dalam setiap kegiatan. Dewan Pembimbing Lapangan (DPL) Bapak Apt., H. Aan Kunaedi, M.Sc dan juga para jajaran LPPM Universitas Muhammadiyah Cirebon atas membimbing dan masukan hingga kegiatan terlaksana baik. Kerjasama dan kekompakan seluruh team kelompok KKM Kecamatan Gunung Jati sehingga semua kegiatan dapat terlaksana dengan lancar. Semoga kegiatan yang sudah terlaksana memberikan bermanfaat dan membantu untuk meningkatkan perekonomian warga setempat. 


\section{DAFTAR PUSTAKA}

Putri, Rizky Fadhlina dan Rini Fadhillah Putri. (2018). Pelatihan pemanfaatan barang bekas menjadi barang yang bernilai ekonomi. Jurnal pengabdian masyarakat, 2 (1), 150-155.

Setiorini, Indah Lestari. (2018). Pemanfaatan barang bekas menjadi kerajinan tangan guna meningkatkan kreativitas masyarakat Desa Paowan. Jurnal pengabdian, 2 (1), 53-61.

Fikri Hadi, M. dkk. (2017). Pemanfaatan barang-barang bekas yang bernilai ekonomi bagi peningkatan produktivitas jiwa entrepreneur ibu rumah tangga Rt. 01 Rw. 12 Desa Limbungan Kecamatan Rumbai Pesisir. Jurnal pengabdian untuk mu negeri, 2 (1), 42-47.

Anindita, Galih. dkk. (2017). Pemanfaatan limbah plastik dan kain perca menjadi kerajinan tangan guna meningkatkan kualiras sumber daya manusia. Seminar MASTER, 173-176.

Sunarsi, Denok. dkk. (2019). Penyuluhan wirausaha home industry untuk meningkatkan ekonomi keluarga dengan daur ulang barang bekas. Jurnal pengabdian pada masyarakat, 1 (4), 188-193.

Sari, Mella Katrina. dkk. (2018). Peningkatan kreatifitas ibu-ibu PKK Pesurungan Lor melalui pemanfaatan barang bekas rumah tangga menjadi produk Decoupage bernilai estetikonomis. Jurnal Abdimas PHB, 1 (2), 105-110.

Laila, Alfi dan Sutrisno Sahari. (2016). Penigkatan kreativitas dalam pemanfaatan barang- barang bekas pada mata kuliah media pembelajaran. Jurnal pendidikandasar nusantara, 1 (2), 1-15.

Marliani, Novi. (2014). Pemanfaatan limbah rumah tangga (sampah organic sebagai bentuk, implementasi dari pendidikan lingkungan hidup. Jurnal formati, 4 (2), 124-132.

Haryono, Didi. dkk. (2018). Pemanfaatan sampah plastik untuk dijadikan bantal yang berkualitas dan bernilai ekonomis di Desa Tolada Kecamatan Malangke Kabupaten Luwu Urara. Jurnal pengabdian masyarakat, 1 (1), 8-13.

Gunartia. dkk. (2019). Memanfaatkan barang bekas untuk menumbuhkan ekonomi kreatif di kalangan masyarakat (majrlis ta'lim Al Hidayah Benda Baru Pamulang). Jurnal pengabdian DHARMA LAKSANA mengabdi untuk negeri, 2 (1), 24-31. 


\section{DOKUMENTASI KEGIATAN}

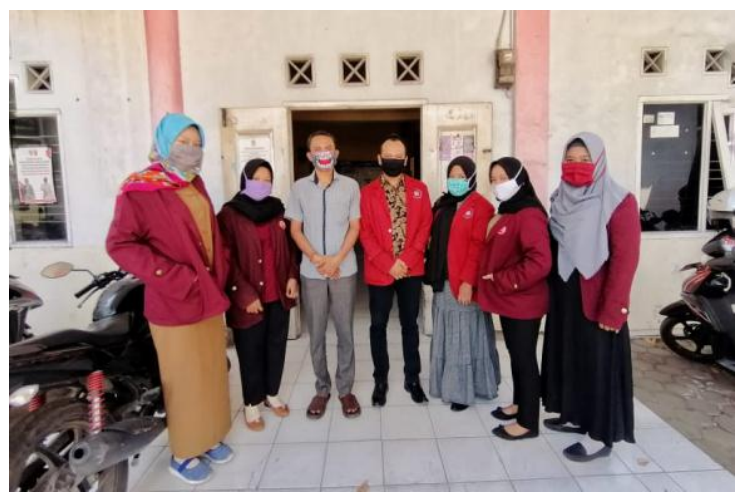

Gambar 1. Survey dengan perangkat desa klayan

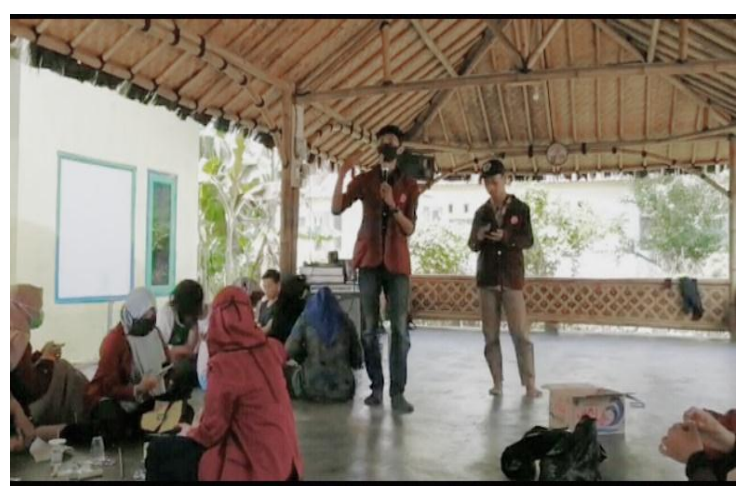

Gambar 2. Penyampaian materi

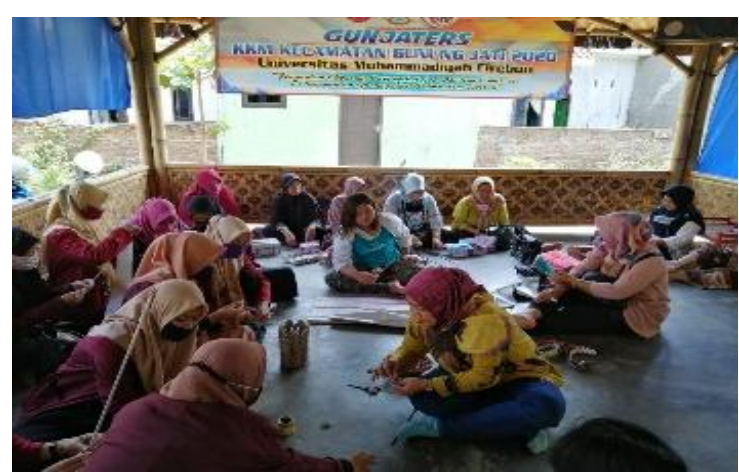

Gambar 3. Pelatihan barang bekas

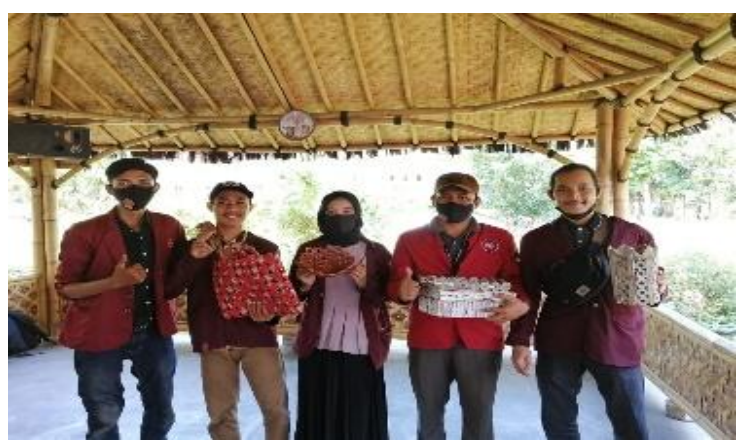

Gambar 4. Hasil karya pengeloaan sampah 